This is the postprint version of the article:

Mattalia, G., Volpato, G., Corvo, P., \& Pieroni, A. (2018). Interstitial but Resilient: Nomadic Shepherds in Piedmont (Northwest

Italy) Amidst Spatial and Social Marginalization. Human ecology, 46(5), 747-757.

\title{
Interstitial but resilient: Nomadic shepherds in Piedmont (Northwest Italy) amidst spatial and social marginalization
}

\author{
Giulia Mattalia ${ }^{\mathrm{a}}$, Gabriele Volpato ${ }^{\mathrm{a}}$, Paolo $\mathrm{Corvo}^{\mathrm{a}}$, Andrea Pieroni $^{\mathrm{a}}$ \\ ${ }^{a}$ University of Gastronomic Sciences, Pollenzo/Bra (Cuneo) Italy
}

\begin{abstract}
Mobility, nomadic pastoralists' main adaptive strategy, has been compromised by agricultural expansion and rangeland fragmentation, among other factors, in many pastoral contexts. Among nomads' coping strategies, is re-shaping mobility in shrinking grazing grounds. Through semi-structured interviews, we examine adaptation and resilience to the effects of increasingly intensive land use and marginalization focusing on Alpine nomadic pastoralists in Piedmont, Northwest Italy. Our results show that Alpine nomads access a wide variety of grazing grounds through a web of social relations with multiple stakeholders, acting in the interstices of mainstream society and navigating marginal contexts: geographically, they use fallow, abandoned, and post-harvest plots; economically and socially, they interact with other marginal groups (e.g.,migrants) and are stigmatized by diverse sectors of society. This use of interstitial spaces is in itself a form of adaptation that is taking place in diverse geographical contexts as nomads reconfigure their mobility and social relations to access the scattered pieces of land left unused by industrial, agricultural, and conservation land uses.
\end{abstract}

Keywords: Nomadic pastoralism; Transhumance; Europe; Resilience; Sheep husbandry

\section{Introduction}

For thousands of years, pastoral nomadism has allowed humans to occupy the most marginal areas of the world in terms of vegetal biomass production. The exploitation of patchy and seasonal grazing resources has subsumed the deployment of mobility as main technical strategy (López-iGelats et al. 2016, Niamir-Fuller 1998). Pastoral mobility has been compromised by agricultural expansion, rangeland and landscape fragmentation, intensification of livestock husbandry, increased labor costs, and political and institutional marginalization in many pastoral contexts (Fernandez-Gimenez and Le Febre 2006, Galvin et al. 2008). As a consequence, the number of nomads, i.e. mobility-based pastoralists, has been declining worldwide, along with local breeds, products, and gastronomy, as well as forms of associated culture, knowledge, practices, and rituals. Pastoral populations are in transition as they try to cope with climatic, environmental, and social change (Thornton et al. 2009, Nori and Davies 2007). Some literature about pastoralists has been predicting their demise for at least a century, and yet pastoralism continues, displaying a great degree of resilience and adaptive capacity. Pastoral nomads have adapted in a variety of ways, including diversification into other (non-livestock) productive strategies, diversification of the livestock portfolio, specialization on specific products, animals, and breeds, or production strategies, also maintaining mobility by re-shaping it into changing contexts, e.g. traveling further, motorizing livestock transport (Fernandez-Gimenez and Le Febre 2006). Several studies have addressed pastoral systems' resilience in a changing world (Dong et al. 2016, Niamir-Fuller 1998, Robinson and Berkes 2010, Wu et al. 2014). However, scholars have paid less attention to how pastoral systems adapt to changes (e.g. in land tenure and use, urbanization, agricultural intensification) that are squeezing them to the margins socially, economically, and geographically. To understand and discuss the ways and means through which nomadic shepherds adapt to the effects of increasingly urbanized contexts and intensive land use, we investigated nomadic shepherding in Piedmont, Northwest Italy, focusing on the system's adaptation and resilience through marginalization at multiple levels.

Alpine nomadism, as this pastoral system is sometimes called (in Italian pastorizia vagante, lit. 'wandering pastoralism'), is a form of mobility-based sheep husbandry widespread in several 
This is the postprint version of the article:

Mattalia, G., Volpato, G., Corvo, P., \& Pieroni, A. (2018). Interstitial but Resilient: Nomadic Shepherds in Piedmont (Northwest Italy) Amidst Spatial and Social Marginalization. Human ecology, 46(5), 747-757.

regions of North Italy (Nori and De Marchi 2015, Verona 2016, De Marchi 2010, Verona 2006, Perco 1982). It can be conceptualized as a form of transhumance, as these shepherds and their flocks seasonally exploit complementary resources on highlands and lowlands (Bunce et al. 2004, Ruiz and Ruiz 1986, O'Flanagan, Lasanta Martinez, and Errea Abad 2011, Mack, Walter, and Flury 2013, Liechti and Biber 2016, Juler 2014). But unlike contemporary forms of European transhumance, in which the animals are stabled during winter, in Alpine nomadism winter mobility is retained and focuses on forage resources available in the intensively used lowlands. It is then composed of a vertical transhumance and a winter horizontal transhumance or wandering, retaining year-round mobility by using seasonal, marginal, and interstitial resources (Falah 1990, Aime, Allovio, and Viazzo 2001, Fernandez-Gimenez and Le Febre 2006) and thus exploiting the configuration of the territory (with mountain pastures very close to lowlands) and the patched distribution of grazing resources with a livestock portfolio that includes sheep, goats, and donkeys (Nori and De Marchi 2015). Decisions related to the movements depend on several ecological, social, economic and political factors and cannot be easily foreseen (Huband, McCracken, and Mertens 2010, Akasbi et al. 2012).

Although nomadism is commonly associated with environments with low human population density and extensive rangelands (Blench 2001, Dong et al. 2016) and it is sometimes considered not compatible with agricultural industrialization policies and land use (Eriksson 2011), Alpine nomadism occurs in a highly industrialized agricultural and densely populated area, e.g. the Po Valley, and the surrounding mountains. As such, it depends on the ability of shepherds to find interstitial grazing grounds not only geographically (e.g. between corn fields, cities, road infrastructures, private fields, protected areas) but also socially and politically, among others' economies and lands (Aime, Allovio, and Viazzo 2001). In a similar but more complex context as that in which tribal nomads negotiate access to land with other tribes, Alpine nomads build and rely on a wide range of social relationships to access fields with their flocks (Blench 2001).

Mobility-based forms of livestock husbandry have witnessed a steep decline during the last hundred years in favour of intensive forms of animal husbandry based on stabling and economies of scale rather than mobility (Lozny 2013). Of the wide web of pastoral movements that used to connect European mountain pastures with lowlands and cultivated areas, only truncated forms survive (Kerven and Behnke 2011). The lowlands and valleys have been engulfed in housing, infrastructure, factories, and intensively-cultivated fields, leaving little place for sheep, while economies of scale have favoured intensive husbandry in the lowlands and marginalized local mountain production. Several institutions and organizations (e.g. Slow Food, the European Union) have been calling for a revalorization of mountain productions and a reactivation of traditional forms of landscape management, thus recognizing the importance of supporting forms of livestock husbandry based on mobility and rooted in the territory (Kerven and Behnke 2011, Eriksson 2011). EU and other institutions' policies influence shepherds' decision making and reverberate across the environmental, social, and political landscape (Eriksson 2011, Nori and De Marchi 2015).

This paper addresses Alpine nomadism in Piedmont with the aims to describe and discuss: 1) The nomadic shepherds, their flocks, and livelihood practices; 2) The landscapes used and navigated and how they are perceived by shepherds; 3) The social relations and networks established by shepherds; and 4) The adoption of marginalization at multiple levels and interstitiality as strategies to adapt to a changing socio-economic environment. We first describe Alpine nomadism (e.g. shepherds, flocks, economic purpose, itineraries) and shepherds' categorization of the landscapes they wander with their flocks. We then address the wider links that these shepherds have with the 'outside' world and of the ways in which the outside world shapes Alpine nomadism. Finally, we discuss the results in terms of the degree of resilience that mobility provides to Alpine pastoralism, highlighting the similarities that interstitial forms of pastoralism hold in widely different geographical and social contexts.

\section{Background}


This is the postprint version of the article:

Mattalia, G., Volpato, G., Corvo, P., \& Pieroni, A. (2018). Interstitial but Resilient: Nomadic Shepherds in Piedmont (Northwest Italy) Amidst Spatial and Social Marginalization. Human ecology, 46(5), 747-757.

Piedmont is a region in North-western Italy with over 4 million inhabitants and a population density of 173 persons $/ \mathrm{km}^{2}$. Mountains cover about $40 \%$ of the regional area, while hills and plains $30 \%$ each. Corn and winter wheat are the main crops in the plains, apart from northern Piedmont where rice fields predominate. Livestock husbandry and transhumance have historically been integral part of the Piedmont foodscapes, with a widespread use of mountain pastures during summer and a diversity of livestock breeds and livestock-derived products.

Sheep-based Alpine nomadism has a thousand years old history in Piedmont, where shepherds used to move seasonally from the summer mountain pastures to the winter plains and vice versa (Carbonero 2006, Bini and Vicquèry 2013). The use of mountain pastures in the Western Italian Alps has been shown to go back to more than 5,000 years ago (Pini et al. 2017). The prevalent use of sheep in this system has shifted through time, from a multi-purpose use (i.e. milk, meat, and wool) to an increasing degree of productive specialization into meat production. Sheep milk was widely used for cheese making in the Po plain until the $13^{\text {th }}-14^{\text {th }}$ centuries, when a tendency to be replaced by cow milk began (Montanari 2003, Ristorto 1990). In the 1920s, a portion of the region (the left banks of the Po river and areas between the low valleys Sangone and Susa and Dora Baltea) was mainly grazed by cattle while a larger portion (the right banks of the Po and its tributaries, from Cuneo and the hilly areas of Roero and Monferrato north to Turin and the plains around Vercelli and Novara) was mainly grazed by sheep (Roletto 1920). Nowadays, cattle husbandry is more important (e.g. in economic terms and cultural relevance) than sheep husbandry over most of the Region's area. Furthermore, the decline in value and request for wool, which shepherds used to sell to local factories, in the last century further pushed shepherds towards a specialization into meat production and meat-oriented productive systems (Corti 2004). The typical breed has always been the Biellese sheep, which is still one of the most important sheep breed in northern Italy.

Across the centuries, shepherds continuously adapted their movements in accordance with the changes in land use occurring in the highlands (e.g. allocation of the best grazing grounds to cattle) as well as in the lowlands, where they had to negotiate their transit and access with different landowners and stakeholders (e.g. tolls paid to Benedictine monasteries for transit, negotiations with farmer for access to stubbles, (Roletto 1920). In different areas of the region, a combination of ecosystems has been seasonally used by shepherds and their flocks. For example, shepherds of Valsesia used to spend the winter in the baraggia, a dry heather moorland with scattered forest trees. The baraggia still is a crucial ecosystem for the survival of Valsesian pastoralism vis a vis the spread of intensive agriculture in the Piedmont plains (Bini and Vicquèry 2013).

Notwithstanding the historical importance of Alpine nomadism and transhumance in Piedmont and North Italy in general, the last thirty years have witnessed a drastic decline in livestock farms ($74 \%$ ) and a concomitant livestock concentration in larger farms. The decline was particularly evident in the hills $(-26 \%)$ and in the mountains $(-36 \%)$, with obvious repercussions on land maintenance and ecosystem management (Regione Piemonte 2017). In Roaschia (Southern Piedmont), where the local sheep breed (the Frabosana or Roaschina) is an excellent milk producer and sheep husbandry has a long standing history, the number of sheep collapsed since the Second World War to the point that Roaschian pastoralism has almost disappeared and the Frabosana is listed among the endangered ovine breeds (Errante 2013, Aime, Allovio, and Viazzo 2001). Negative trends for mobility-based pastoralism in North of Italy are the result of a number of concurring factors such as increasing intensification of livestock husbandry, abandonment of marginal areas and small-scale productive strategies, and increasing land use intensification especially in the lowlands. The research question in this context relates to the ways and extent to which Alpine nomads cope with a changing socio-economic environment and adapt their mobilitybased pastoral system to a fragmented landscape accessible through multi-level and diffuse social relations.

\section{Methodology}


This is the postprint version of the article:

Mattalia, G., Volpato, G., Corvo, P., \& Pieroni, A. (2018). Interstitial but Resilient: Nomadic Shepherds in Piedmont (Northwest Italy) Amidst Spatial and Social Marginalization. Human ecology, 46(5), 747-757.

Fieldwork was carried out between March and May 2017 in Piedmont, and included literature review, public data retrieving, and semi-structured interviews with nomadic shepherds and other stakeholders. Data collection consisted of two phases. The first phase included data collection from the four animal health authority offices in Piedmont where shepherds submit their request for nomadic grazing, thereby listing species and number of animals and the itineraries followed municipality by municipality, day by day, within one-year period during 2016 . The second phase consisted of anthropological fieldwork methods (Bernard 2006) such as participant observation and in-depth semi-structured interviews with twenty nomadic shepherds (all men, from 20 to 80 years old, mean age 49) selected randomly from the list in phase 1 (two restrictions were applied: only shepherds who graze in more than 4 municipalities and including sheep in their herd were considered). Shepherds were first contacted by phone and then, upon their acceptance, visited directly in the field. Questions included herd size, movements and itineraries, perceived environments, relations with EU subsidies, local and regional institutions, and owners of private lands, market involvement, constraints and opportunities. Interviews lasted for two to three hours, were conducted in the field in Italian language, recorded, and later transcribed. The transcriptions and notes taken during fieldwork are the study's qualitative data, which were coded and analyzed narratively (description, explanation, interpretation, quotations) and through descriptive statistics. Participants were given an explanation of the methodology, aims, and outcomes of the study, and informed consent was obtained verbally before interviews were conducted. Throughout the field study, the ethical guidelines adopted by the American Anthropological Association (AAA 1998) were followed.

\section{Results and discussion}

\section{The shepherd and his herd}

According to the data collected, there are 65 fully nomadic sheep flocks in Piedmont. They move all over the region, especially in mountainous and hilly areas and along river banks (e.g. Po, Sesia, Tanaro, Ticino). Areas with little Alpine nomadism include the intensively cultivated plain of Cuneo (in the south of the region) and partly the area around Turin. Herd size ranges between 400 and 3000 sheep. Shepherds claim that an herd with less than 500 sheep is not economically viable, while the maximum viable herd seems to be of about 1500 sheep (Table 1).

\begin{tabular}{|l|l|l|l|l|}
\hline & Torino & Cuneo & Alessandria & Novara \\
\hline Small $(<500$ sheep $)$ & 7 & 4 & 2 & 10 \\
\hline Medium $(500 \leq x<1500)$ & 10 & 2 & 4 & 10 \\
\hline Big $(\geq 1500$ sheep $)$ & 2 & $/$ & $/$ & 3 \\
\hline TOTAL & $\mathbf{1 9}$ & $\mathbf{6}$ & $\mathbf{6}$ & $\mathbf{2 3}$ \\
\hline
\end{tabular}

Table 1. Number of sheep per herd per zone (data collected from Health authority office)

The few available data from other regions of North Italy show a comparable number of nomadic shepherds; in Lombardy, 60 shepherds have about 60,000 sheep or about 1,000 per flock (Regione Lombardia 2013).

Some $85 \%$ of the shepherds interviewed have only sheep of the Biella breed, the others having Bergamo sheep or a mix of them. However, nomadic flocks never consist of sheep only, rather always including a variable number of goats (in proportion of one tenth or less than the sheep), some donkeys (from few to fifteen, they provide transport of goods and lambs, especially during the seasonal movements up and down the mountain pastures), as well as a variable number of dogs (both guardian dogs for animal predators and thieves and shepherd dogs to manage the flock), according to the season, the characteristics of the grazed environments, and access to EU subsidies. About one third of the shepherds also have few cows, used for milk production for home consumption, moving along with the flock. According to some informants, in the past chicken and 
This is the postprint version of the article:

Mattalia, G., Volpato, G., Corvo, P., \& Pieroni, A. (2018). Interstitial but Resilient: Nomadic Shepherds in Piedmont (Northwest Italy) Amidst Spatial and Social Marginalization. Human ecology, 46(5), 747-757.

rabbits were at times part of the livestock portfolio, in a veritable nomadic farm. Within this livestock portfolio, goats play an important role because they nurse lambs whose mothers refused them or have mastitis. Also, the browsing habits of goats (e.g. of bushes and brambles) are complementary with sheep's grazing habits, thus allowing the shepherd to use a field more efficiently as well as contrasting the growth of secondary forests on abandoned plots. However, goats' browsing habits can also damage valuable plants such as young poplars in reforestation areas or pulp-production plantations.

Flocks' daily routine includes grazing in the morning and in the afternoon, and spending the nights in mobile fences. Shepherds move along and live in caravans; many have families in a settled house, where they go back once a week or more according to the distance. Herding units (i.e. labour force) mainly consist of one shepherd and one (or more) helpers (in $40 \%$ of the units). Other common herding units include the shepherd, his wife, and some helpers or the shepherd, some relative(s) and/or helpers. Within the herding unit, the shepherd is the one who takes decisions, rarely leaves his flock, and holds a long nomadic experience. Because there is a frequent turnover of helpers, few of them have the knowledge to take decisions about flock management. In recent years, some authors have stressed the key role of migrants for the resilience of Euro-Mediterranean, including Italian, pastoral systems (Nori 2014, Nori and De Marchi 2015, Huband, McCracken, and Mertens 2010). In line with these findings, most of the helpers we met are Romanian, particularly from the area around Bacau, and have had experience with herding in their home country. Women, shepherds' wives, are usually in charge of bureaucratic tasks, keeping contacts with animal health and local authorities. They also act as caregivers for lambs and sick sheep, since women often have a partially stable foothold. If the herding unit also owns cattle, this is cared for by women. In addition, food provision (including sometime cheese-making for their own use) is a daily assignment for wives. If included in the herding unit, relatives as son, son-in-law or grandchildren are firstly responsible for helping (and learning from) the shepherd.

About $80 \%$ of the shepherds do not have other income than the one obtained from sheep (meat only) and in some cases cow (for milk and cheese production). About $20 \%$ of the shepherds have also some other income (Figure 1), e.g. from trading sheep, as hired shepherds in Switzerland during summer time, as night guard, or from pensions.

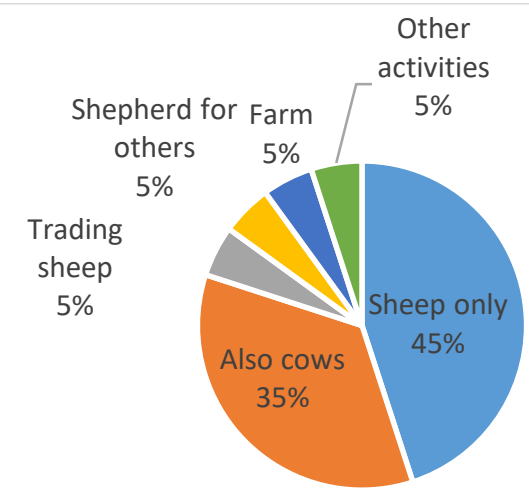

Figure 1. Shepherds' income sources

\section{The shepherd and his landscapes}

Year-round mobility, particularly winter mobility in the lowlands, is the distinguishing trait of Alpine nomadism versus contemporary forms of Alpine transhumance. Hence, we interviewed shepherds about their yearly movements and plotted these on the map (Figure 2, each shepherd with different colour), recording also the time and reasons for choosing or not a particular grazing location. The twenty itineraries show the actual movement of each informant during the year 2016 . 
This is the postprint version of the article:

Mattalia, G., Volpato, G., Corvo, P., \& Pieroni, A. (2018). Interstitial but Resilient: Nomadic Shepherds in Piedmont (Northwest Italy) Amidst Spatial and Social Marginalization. Human ecology, 46(5), 747-757.

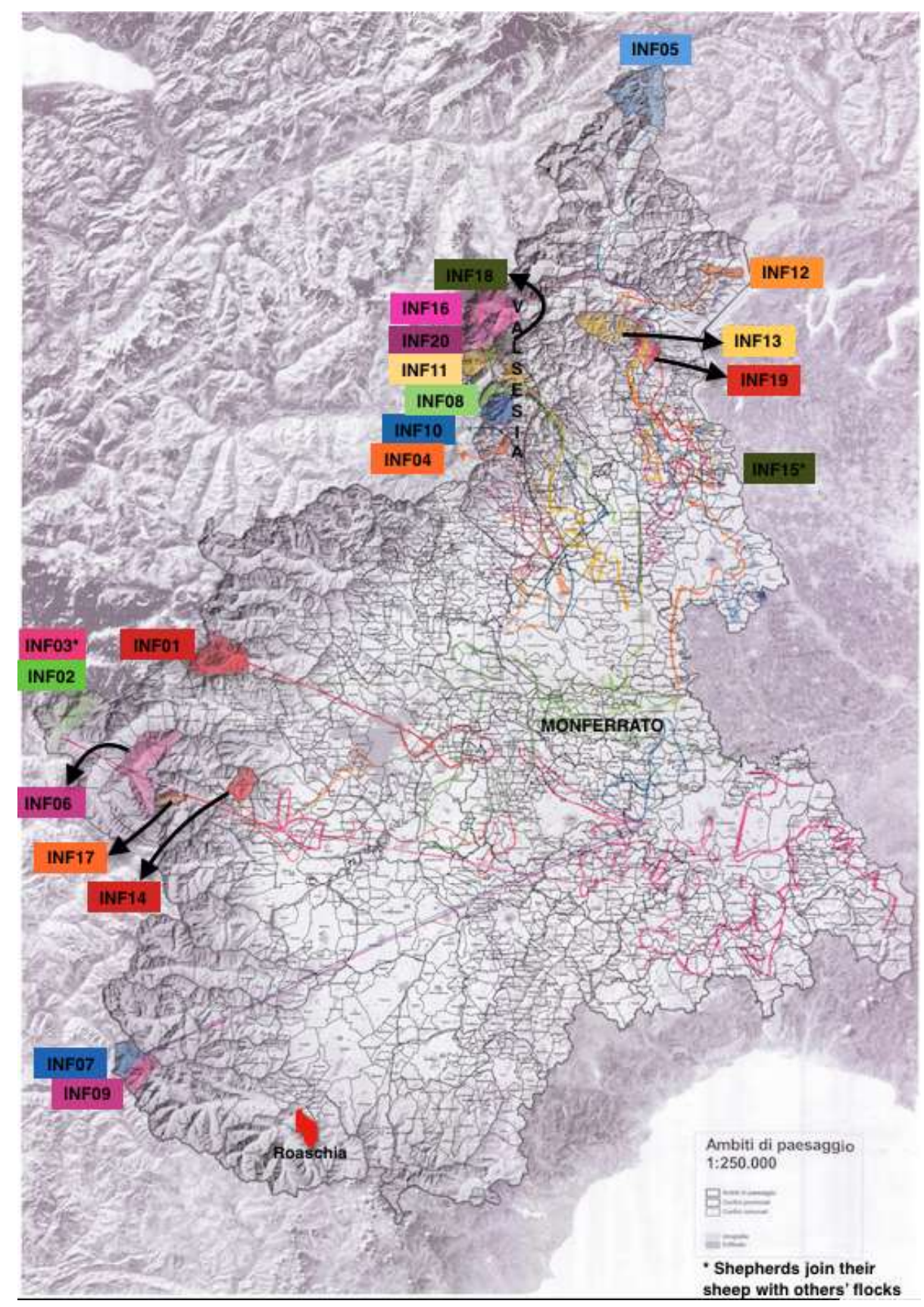

Figure 2. Itinerary 20 interviewed shepherds took in 2016 (the places named in the map are also mentioned in the text)

The routes taken are variable, both among shepherds as well as from year to year for the same shepherd. All the itineraries have in common a transhumant movement between the lowlands and the mountains, as well as somewhat a fan shape, with on one side the precision of mountain grazing and on the other side the flexible itineraries in the plains, which open as a fan in the interstices of the lowlands. South-western Piedmont is devoid of Alpine nomadism because is intensively cropped with corn and wheat, with shepherds often crossing the cultivated plain by truck (hence the straight line on the map). Several shepherds spend the winter in Monferrato, an hilly area characterized by small allotments, a variety of crop fields, and substantial landscape and ecosystem diversity. The transhumant movement is similar in North Piedmont, though flocks there tend to spend the winter in rice fields and river banks, before climbing the Pennine and Lepontine Alps in late spring.

Yearly movements can be grouped in four main periods (Table 2) defined by the continuous 
This is the postprint version of the article:

Mattalia, G., Volpato, G., Corvo, P., \& Pieroni, A. (2018). Interstitial but Resilient: Nomadic Shepherds in Piedmont (Northwest Italy) Amidst Spatial and Social Marginalization. Human ecology, 46(5), 747-757.

pendulum between highlands and lowlands and their transition phases. Alpine nomads and their flocks spend about four months per year in the highlands, exploiting the forage-rich pastures during the summer season. The movements up and down the mountains are mostly done by foot (particularly the return to lowlands), fewer times by truck, and can last one month or more with the flock moving daily. During the descent, flocks follow river banks and graze from fallow fields before moving from the beginning of October to cultivated fields (e.g. vineyards) and meadows, in accordance with agricultural cycles. In winter, flocks graze in hilly and flat areas, navigating different anthropic and semi-natural environments.

\begin{tabular}{|l|l|}
\hline Season & Activity \\
\hline Oct-Nov to May-Jun & Lowlands grazing \\
\hline May-Jun & Transition (transhumance to highlands) \\
\hline Jun to Sep-Oct & Highlands grazing \\
\hline Sep-Oct & Transition (transhumance to lowlands) \\
\hline
\end{tabular}

Table 2. Yearly movements of nomadic shepherds in Piedmont

When asked to free list and describe the environments they move across, shepherds provided a highly nuanced understanding of the landscape around them, listing a total of forty perceived environments (Table 3, we did not include the environments mentioned by just one informant). Every informant reported both a horizontal and a vertical transhumance, which included a variety of landscapes such as mountain pastures, hilly areas, river banks, as well as city parks (two shepherds bring their flock to graze in the outskirts of Turin, one of them in the Parco del Valentino, at the very centre of the city), roadsides, and abandoned plots. 


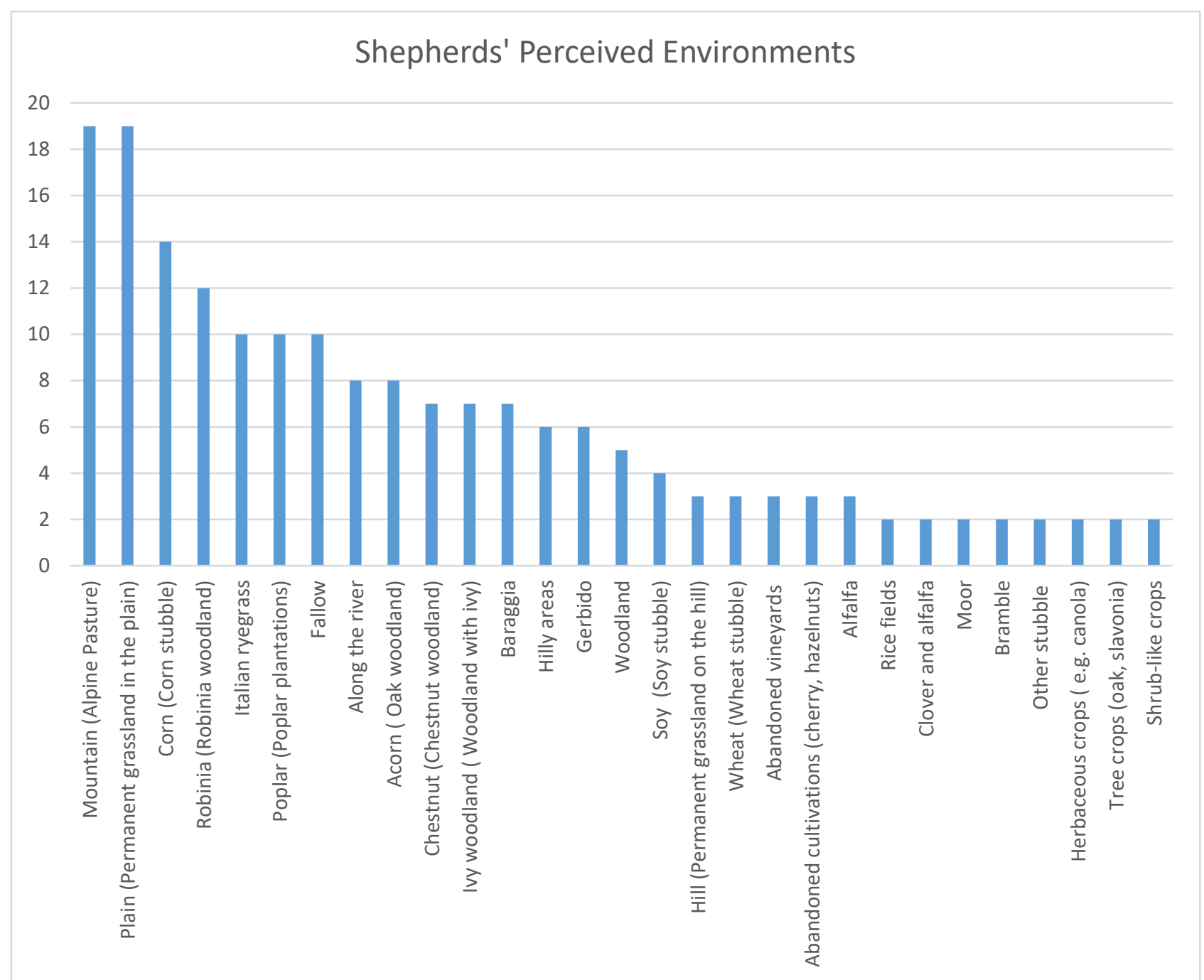

Table 3. Number of quotations per perceived environment

\section{Alpine pastures}

Alpine pastures (up to 3,000 m asl) were mentioned by all informants but one and are the most cited landscape used for grazing. Alpine pasture as a landscape is not further differentiated by informants, ${ }^{1}$ which contrasts with the vast differentiation made regarding winter landscapes (see below). Sixty percent of the informants regard Alpine pastures as 'the best they can offer to their sheep', with abundant water and grass, claiming that the grass is very nutritious ('the grass never gets old', 'sheep eat little but they are always full'), though sometimes limited in quantity. Most shepherds further report that the quality of the grass increases with altitude, envisioning 'centuriesold grasses, born directly from the mountain itself.' Among these grasses, Ligusticum mutellina ('as thin as a parsley'), Trifolium alpinum, Trifolium incarnatum, and Festuca alpina have been mentioned.

As in Northeast Italy (Nori and De Marchi 2015), Alpine pastures are mostly rent by shepherds for the summer season. Alms are allocated through a system of auctions, and this is an important cost and problematic for access to mountain pastures. Nomadic shepherds live in mountain cabs and usually visit more than one cab per summer season, moving from the lower (at intermediate altitudes' grasslands and meadows) to the highest (permanent grasslands at 2,000 $\mathrm{m}$ and above) and back. Most of these cabs have no water or electricity guaranteed; some are better equipped and can

\footnotetext{
${ }^{1}$ Only one shepherd distinguished Alpine pasture in two different areas: the drua, an area close to the cabin with higher fertility due to continuous presence of livestock, and the giavina, highland grasslands dotted with stones.
} 
This is the postprint version of the article:

Mattalia, G., Volpato, G., Corvo, P., \& Pieroni, A. (2018). Interstitial but Resilient: Nomadic Shepherds in Piedmont (Northwest Italy) Amidst Spatial and Social Marginalization. Human ecology, 46(5), 747-757.

be reached by motorized transport. A positive aspect of Alpine pastures according to informants is the lack of intensive agriculture and hence of residues from chemical weeding and pesticides on the vegetation, with an overall better health of the animals. From the shepherd point of view, it is also a positive time of the year, when 'days are beautiful and there is not a lot of bureaucracy [as the one needed to navigate the lowlands].' Problems include the presence of wolves, conflicts with tourism and tourists (e.g. regarding the relations between guardian dogs and tourists, the conversion of grazing grounds in touristic facilities), increasing prices of mountain alms, and the somewhat precarious living conditions, often without a proper cabin, road access, or telephone network. Sheep husbandry in mountain pastures suffers the competition of cattle husbandry, which usually occupies the better pastures due to cattle herders' capacity to pay higher rents and their utilization of alms with cheese-making facilities, which are also those with better infrastructure. Instead, sheep husbandry is marginalized to higher elevations and to pastures of difficult access, i.e. those lacking cheese-making facilities and hence assigned to meat flocks and herds, and those with steeper grazing grounds and hence assigned to sheep.

Wolves have recolonized the Alps, including Piedmont's mountainous and hilly areas, during the last twenty years after almost a century of absence (Marucco 2014). The establishment of wolf packs in the highlands have generated alarm and tensions among livestock owners who had since generations abandoned the measures necessary to reduce the probability of wolves' attacks. A sometimes harsh debate is ongoing in Italy about the presence of wolves in the Alps and their impact on local livestock husbandry (Lescureux and Linnell 2010, Nori and De Marchi 2015, Verona, Corti, and Battaglini 2010). In spite of this, no informant reported wolves' predation on their flocks nor considered wolves a main problem. The lack of reported wolf attacks by our informants is surprising given the several cases of wolf predation on domestic livestock that occurred in the Alps in the last twenty years and given that big nomadic sheep flocks are theoretically more difficult to guard and easier target for wolves (Verona, Corti, and Battaglini 2010, Borgia 2003). Shepherds are aware of the risks connected with wolves' presence in the mountains, and never leave their flock unattended, but overall they regard, as one of them stated, that 'chemical products on the plain kill more than wolves in the mountain' (cfr. (Bini and Vicquèry 2013).

\section{Lowlands' permanent grasslands and cultivated fields}

Permanent grasslands and cultivated fields on the plains and on the hills have been mentioned by 19 and 3 informants respectively (most shepherds refer to them simply as grasslands) and are the most important winter pastures. They are regarded as 'fat', as they have fertile soils and include abandoned and hay-making fields. Forty percent of the shepherds rent these fields from late autumn to winter as they are regarded the best pastures for their good grass and the relative easiness in monitoring the flock. On the negative side, when it is rainy these fields turn quickly into muddy areas not suited for grazing.

Grasslands on the hills are highly regarded for the diversity and quality of their grasses ('grasses have a different taste up on the hill'). However, increasingly fewer shepherds are using hilly grasslands due, according to informants, to two suites of motives. The first relates to the relative small size of grazing parcels there and to the increasing average flock size for economic viability: as economic returns per sheep head decline through time due to the marginal economic position of nomadic shepherds, economic viability is achieved by increasing the flock size, in an attempt to increase gains by lowering production costs (Nori 2014). As a backdrop, shepherds select against smaller grazing plots because of the difficulties in managing the flock there, in doing this selecting somewhat against grasslands on the hills. Indeed, in North Italy Alpine nomadism, average herd size increased from 100-150 sheep a century ago to about one thousand today, along with a specialization in meat (rather than milk or cheese) production (Regione Lombardia 2013). The second motive relates to the depopulation of hilly areas and their abandonment as productive areas, which according to informants means less fertilization and lower grass quantity and quality, as well as more abandoned areas unsuitable for grazing. The case of grasslands on the hills shows how 
This is the postprint version of the article:

Mattalia, G., Volpato, G., Corvo, P., \& Pieroni, A. (2018). Interstitial but Resilient: Nomadic Shepherds in Piedmont (Northwest Italy) Amidst Spatial and Social Marginalization. Human ecology, 46(5), 747-757.

nomadic shepherds intersect and cope with wider changes that have occurred in North Italy during the last fifty years, including industrialization, urbanization, intensification of production on the lowlands, depopulation of marginal and mountainous areas, abandonment of agriculture and loss of landscape management, and growth of secondary thickets and forests over abandoned fields.

Cultivated fields are also important for provision of stubbles. Corn, soy, wheat, and oat stubbles, in order of mentions, are an important source of proteins for nomadic flocks. Corn stubbles are the most popular but shepherds limit their access by sheep claiming that too many cause swelling and death by rumen block. Hence, some herders avoid corn stubbles, others continuously check on any sign of distress after consumption (e.g. 'at night you shouldn't see them full'). Soy stubbles are visited in the early spring, when soy fields' nitrogen fixation provides an early growth of nutritious grass.

\section{Woodlands and poplar plantations}

Black locust, poplar, acorn, and chestnut woodlands, in order of importance, are used as grazing grounds and provide diverse grasses as well as shade. Black locust woodlands were mentioned by half of the informants as palatable for their sheep but also dangerous because the tree's thorns may cause wounds and limps. Poplar woodlands and plantations used to be a key riparian environment for nomadic flocks; shepherds reported a sharp drop of these plantations in recent years, which were often reconverted to corn, wheat, and Italian ryegrass cultivation. Poplars are essential for nomadic flocks because they provide shade, a place which can be easily enclosed, and a soil which does not suffer from trampling when rainy. However, grasses in the understory are not highly esteemed, except for Stellaria media. Acorn and chestnut tree woodlands are typically found in northern Piedmont. However, shepherds reported that chestnut woodland grazing has been compromised during the last decade by the widespread effects of the chestnut gall wasp's invasion on chestnut production (sheep are fond of chestnuts) as well as by the effects of the abandonment of chestnut woodlands and management, which make them 'dirty' (i.e. with load of dead biomass and colonized by brambles) and unsuitable for grazing. Two shepherds attributed to grazing in acorn woodlands and to acorn's medicinal properties a reduced incidence of mastitis in their ewes. Fallow, abandoned plots, and protected areas

Some $80 \%$ of the informants reported grazing their flocks on fallow land, abandoned and unused plots (e.g. abandoned vineyards and cherry-orchards), and brambles. As recognized by the herders themselves, grazing keeps these areas 'clean' by removing dry biomass and halting the colonization of shrubs and brambles, at the same time reducing the damaging impact of wildfires and maintaining the landscape. The economic marginality of nomadic shepherds contributes to the process: smaller fields, turning too small to feed herds of increasing size, are no longer grazed and their management abandoned. 'These nice woodlands used to be a secure source of food for sheep, until few years ago. Now, not even goats can get it, not even wild boards like it, they are jungles!', in the words of one informant.

Sheep grazing is an integral part of landscape management in many European countries, as such providing a plethora of ecosystem and cultural services, such as articulating unused green spaces, maintaining and supporting biodiversity and landscape diversity, preventing the growth of secondary forest, and generating short food chains of culturally-meaningful products (Triboi 2017, Nori and De Marchi 2015, Ross et al. 2016, Manzano and Malo 2006). In the name of these services, shepherds seek access for their flocks also to protected areas and regional parks. However, in recent years traditional winter feeding grounds along the rivers have been declared protected areas by the regional legislation because of their high biodiversity. This has shortened and limited the time that shepherds can spend there, when they are not completely banned due to concerns over trampling, overgrazing, and disturbance of nesting birds (Regione Piemonte 2008). Shepherds argue that they should be allowed access for the ecological benefits of sheep grazing for that same biodiversity that park authorities aim to conserve, and further warn that without grazing the areas will 'turn dirty', with consequences on soil fertility and biodiversity ('no dung, no fertility'). 
This is the postprint version of the article:

Mattalia, G., Volpato, G., Corvo, P., \& Pieroni, A. (2018). Interstitial but Resilient: Nomadic Shepherds in Piedmont (Northwest Italy) Amidst Spatial and Social Marginalization. Human ecology, 46(5), 747-757.

From an ecological perspective, Alpine nomadism uses renewable resources in areas unfit for intensive land uses (e.g. mountain pastures), in unused and abandoned plots, and makes a secondary, seasonal, and complementary use of spaces with other land use priorities (e.g. conservation for river banks, crop production for cultivated fields, hay production in meadows visited after the second or third cut). Absent added grains and feeds, herd size is limited by the biomass produced in these environments and by their accessibility. Accessibility of grazing plots is key to Alpine nomadism's resilience, in terms of geographical accessibility as well as of sociopolitical accessibility. Shepherds need to be able to navigate their social as well as their geographical surroundings to grant their flocks access to grazing resources.

\section{Social and economical relations}

We have described the different ecosystems where shepherds move their flocks, and we have hinted to how shepherds' ability to access these grazing fields is continuously shaped by the wider society. During winter, Alpine nomads wander among municipalities that allow their transit and municipalities that don't, cross busy roads and railways, move their flocks at night to avoid blocking traffic, and struggle to keep flocks out of parks and other protected and forbidden areas (Regione Lombardia 2013). This navigation of the landscape is social as well as geographical. Shepherds need not only to know the geography of places and the characteristics of the grazing resources in each place in different seasons, they also need to establish and maintain a vast array of social relations to be able to access grazing areas and deploy nomadic livelihoods (Figure 3). 


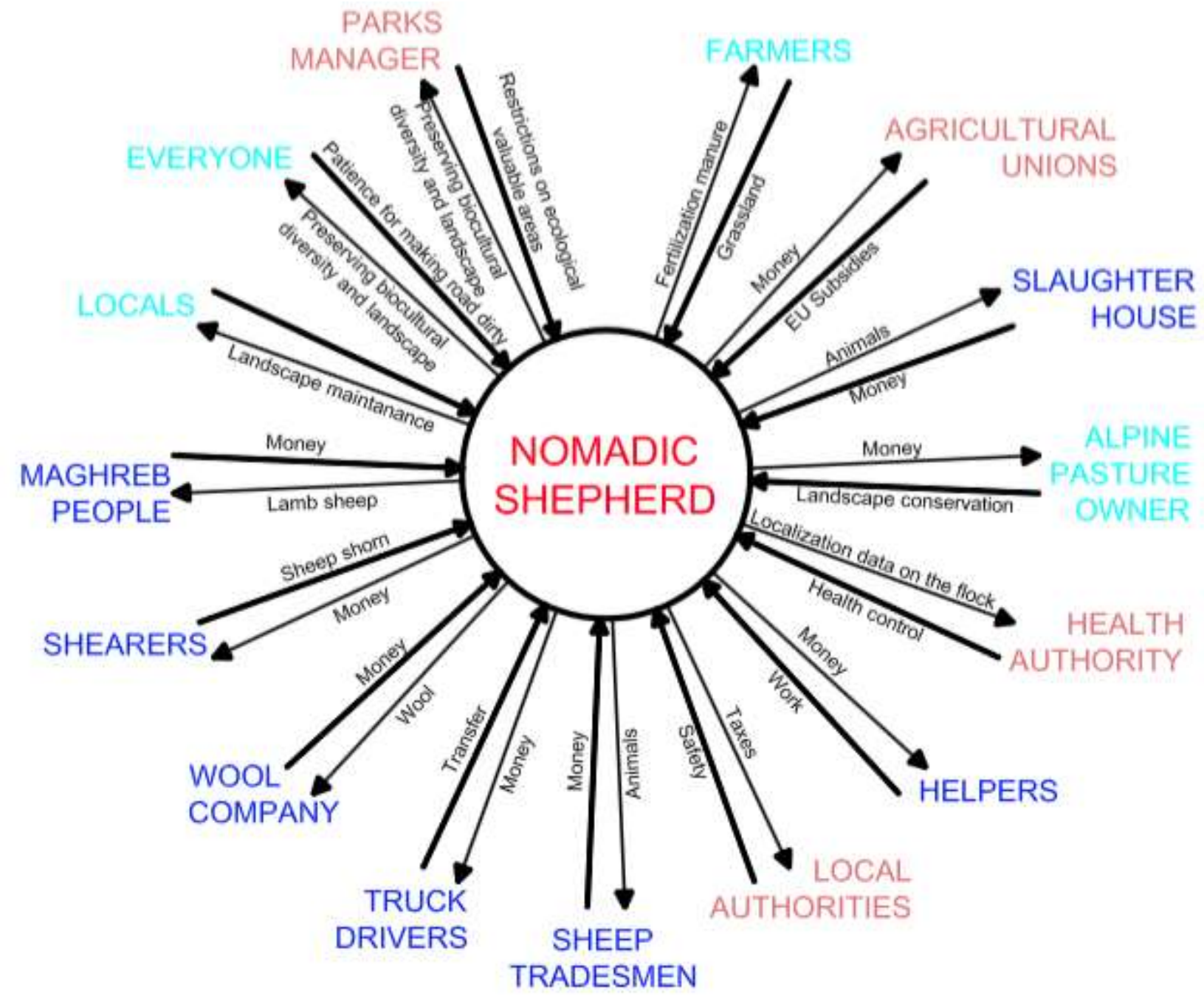

\section{LEGEND}

PARKS MANAGER = POLITICAL

HELPERS $=$ ECONOMIC

Figure 3. Relationships of the nomadic shepherds in Piedmont. Type of exchange (mostly political, social, economic or ecological) and object of the exchange

These diverse relationships are integral to the pastoral system as they make core ecological relations (e.g. the relations between the sheep and the grass, and between the shepherds and the flocks) possible. They take place with social (e.g. farmers, field owners, tourists), political (e.g. agricultural unions, road police, municipal and health authorities, EU), and economical (e.g. shearers, tradesmen, slaughterhouses, customers) actors and are each characterized by the transfer of cash, services (e.g. landscape conservation and management, manure, cultural services, safety, etc.), or products (e.g. lamb meat, cheese, wool) between the shepherd and each stakeholder. As well, shepherds rely on relations with relatives, friends, and other shepherds (Fassio et al. 2014).

These relations form an intricate social web that is paramount to nomadic shepherds, the more so as they move through interstitial spaces of an outer society with other priorities on land use than feeding sheep. Shepherds rely on a continuous renegotiation of access to fields as well as on flexibility about where and when to move. Alpine nomads are skilful in finding interstitial land in an agro-industrialized territory by making a second-hand, non-prioritized use of lands. These skills include social and ecological knowledge. Shepherds know the soil texture (e.g. 'when it's rainy we cannot get in clay soils, so we try to find poplars or we graze along the rivers'), grass composition and effects on livestock, water access and availability, degree of shade and protection from 
This is the postprint version of the article:

Mattalia, G., Volpato, G., Corvo, P., \& Pieroni, A. (2018). Interstitial but Resilient: Nomadic Shepherds in Piedmont (Northwest Italy) Amidst Spatial and Social Marginalization. Human ecology, 46(5), 747-757.

predators and accidents (e.g. in relation with railway networks), and seasonality (e.g. of certain resources, in relation to the amount of snow, etc.), among others, of the different ecosystems they conduct the flock to. As well, shepherds need to balance safety, feeding, and itineraries while moving from parcel to parcel, having regard also of the authorizations needed to cross private and public terrain.

Shepherds have to relate with farmers to get access to their fields in accordance with the agricultural calendar. Some agreements between farmers and shepherds have been institutionalized across the centuries and are still somewhat maintained or enforced based on customary practices. Traditionally, flocks were allowed to freely graze cultivated fields between Saint Martin (November, $11^{\text {th }}$ ) and Saint Joseph (March, $18^{\text {th }}$. When shepherds move to cultivated fields, they usually first contact the farmer for permission, then a scouting is organized to check how to reach the field (e.g. how and where to cross rivers and roads), and eventually a mobile fencing systems is set up to avoid sheep to damage crops. The time spent in each field varies greatly in accordance to the size of the plot and to the palatability and quantity of grazing resources, among other factors. Nowadays, permissions for transit and grazing must be asked to local animal health authorities (who submit the request to the municipality, which can accept or deny transit and grazing) and to the field's owner. The owner may require a payment in cash (an increasingly prevalent mode of transaction) or in livestock products (e.g. a lamb or a piece of cheese). The double permission needed makes the process cumbersome and more expensive, the more so in such a forcibly flexible pastoral system in which movements can hardly be foreseen.

Among the most important relations there are those with the agricultural unions to access European Union subsidies, which are often crucial to shepherds' livelihoods. Indeed, 95\% of the shepherds we interviewed obtain EU subsidies. These have the aim of preserving mobility-based and marginally-located pastoral systems and livelihoods, as well as associated ecosystems and products (Kerven and Behnke 2011, Eriksson 2011). In Italy, they are transposed by each region. For the period 2014-2020, the Piedmont Region provides funds and payments to nomadic shepherds through four main schemes (Marandola and Coderoni 2015, Regione Piemonte 2017): 1) Support to endangered autochthonous breeds; 2) Grazing extensification (e.g. to keep the grazing area clean from weeds and undesired bushes, not to apply pesticides, chemical weeding, or mineral fertilizers); 3) Application of safety systems to prevent canine (e.g. wolves and stray dogs) attacks on the highlands (e.g. electric fences, guardian dogs); 4) Application of the farm pastoral plan on alpine pasture areas. A majority of informants apply to the first two measures each year, the first by introducing sheep of tacola breed, an endangered Piedmont ovine breed, into the flock (10-15\% of the total sheep heads). Regarding the second, most shepherds can only apply for highland subsidies since they do not have any written contract for the lowlands. The third and the fourth schemes are seldom applied allegedly due to the difficulties (e.g. heaviness, difficult of transport due to isolation of grazing grounds, rocky pastures) of using electric fences in marginal mountain pastures. Shepherds are driven through subsidies' bureaucracy by agricultural unions, which are paid through membership. Although economic subsidies are a welcome integration to shepherds' livelihoods, they also attract speculations, with some actors entering the sector only to intercept the flow of subsidies. In the words of one informants, 'they are not shepherds, they have never seen a sheep!'. Albeit obtaining a consistent part of their income through European subsidies, most shepherds regard the schemes as a distortion (albeit a necessary one at the moment) of what their livelihoods should ideally be, i.e. being paid the right price (relative to production costs and margins of profit) for their sheep's meat. But on the one hand their price can't compete with those of intensive livestock husbandry (for complex reasons that include economies of scale, lack of accountancy of intensive farms' externalities in the final price, etc.), and on the other hand lamb, ram, and sheep meat do not have a large market in Piedmont and in North Italy in general. Rams are usually sold alive directly to customers or butcheries, and shepherds eventually fetch low prices for their highquality meat. In this context, nomadic shepherds have in recent years found a market for their meat among Muslim migrants and families from the Maghreb countries, who are at present the main 
This is the postprint version of the article:

Mattalia, G., Volpato, G., Corvo, P., \& Pieroni, A. (2018). Interstitial but Resilient: Nomadic Shepherds in Piedmont (Northwest Italy) Amidst Spatial and Social Marginalization. Human ecology, 46(5), 747-757.

consumers of sheep meat in Italy (Nori and De Marchi 2015). Such a market takes place with a reorganization (often at the fringes of legality) of slaughtering, as Muslim customers demand Halal meat. A large number of rams are requested by the Islamic community for the Aid el-Adha, an Islamic celebration that takes place each year about two months after the end of the Ramadan. A marketing possibility for shepherds is to pursue economic stability by adapting to consumers' demand and synchronize the flock reproduction and availability of lambs and rams to the Islamic calendar and to establish networks with halal slaughterhouses (Nori and De Marchi 2015).

In spite of the marketing difficulties, specialization in meat production is at the moment the path taken by all informants, given the market marginality of cheese and wool, the two other main products traditionally obtained from sheep. Cheese production is hampered by the lack of cheesemaking facilities, investment capacity, and labour force inherent to a form of pastoralism that exploits the margins geographically and socially. Wool had a huge economic importance in Piedmont until the second half of the XIX ${ }^{\text {th }}$ century (Mocarelli 2009): the income from the March shearing paid back the shearers for the all year, and the income from the September shearing went 'under the mattress' (as savings). Nowadays, wool is no longer a reliable source of income, on the contrary regarded as a cost and 'a special waste': sheep are shorn once a year at Easter time and wool, when bought, is paid around $0,30 € / \mathrm{kg}$, which is not enough to pay the shearers.

\section{Interstitial pastoralism}

Contemporary Alpine nomadic pastoralists have turned to migrants and abandoned and fallow fields as strategy for adaptation and resilience. This form of adaptation is also evident in several contexts in which pastoralism loses access to grazing areas as they are converted to other land uses. Interstitial nomadic pastoralism is characterized by five core features: 1) The widespread use of interstitial spaces between other land uses for grazing; 2) Adaptation to movement among these generally unconnected areas (e.g., motorized transport, moving flocks at night, unauthorized grazing and field invasion); 3) Establishment of a wide array of social relations, some potentially confrontational (e.g., with other shepherds, with authorities and conservation institutions and parks, with the average road user, etc.); 4) Interaction of shepherds with other marginal stakeholders and sectors of the mainstream society (e.g., migrants); and 5) A politicization of nomadic livelihoods toward an increasing dependence on wider and complex economic, social, and institutional networks (e.g., EU subsidies). Loss of control over grazing grounds, economic marginality, and cultural oppression are among the drivers that push nomadic pastoralists to geographic and social margins in many parts of the world. Ahmed (1982) describes the Gomal nomads as living 'in the administrative and social interstices of the larger states of Pakistan and Afghanistan'(1101), and nomadic pastoralism as an adaptation to the political as well as to the natural environment. In Romania, extensive sheep husbandry has expanded following decollectivization and the fragmentation of land tenure since the early 1990s, occupying the interstices of urban areas (e.g., roadsides, abandoned plots), though governmental laws and policies have often ignored or devalued this practice (Triboi 2017). Forms of interstitial and urban pastoralism occur in France, where sheep can be seen grazing on the outskirts of Paris, and increasingly local authorities and public and private actors use herds in urban areas for their ecological services of maintaining lawns, abandoned lands, river beds, and urban green areas (Garric 2013; Triboi 2017). In the Laikipia region of Kenya, Maasai and Samburu pastoralists have seen their customary territory greatly reduced since colonization and, more recently, by the expansion of national parks and private conservancies as well as by land grabbing for large-scale agricultural and development schemes. They are being squeezed into the interstices of a territory that they no longer control and of a society with different land use priorities (Letai and Lind 2013). In the process, tension and conflicts are increasing between Laikipia pastoralists and conservation authorities and the wider society. 
This is the postprint version of the article:

Mattalia, G., Volpato, G., Corvo, P., \& Pieroni, A. (2018). Interstitial but Resilient: Nomadic Shepherds in Piedmont (Northwest Italy) Amidst Spatial and Social Marginalization. Human ecology, 46(5), 747-757.

For example, in recent years the Kenyan Army intervened repeatedly to defend private properties from pastoralists seeking grazing grounds for their cattle (German et al. 2017). Similarly, during the dry season, the Maasai of the Kenyan Great Rift Valley move their herds along grassy roadsides and into conservation areas (e.g., lake shores) and agricultural fields, and establish adaptive relations with new stakeholders in their customary land (e.g., the Maasai around Lake Naivasha may seek access for their herds to the green residues from the large-scale export-oriented flower and vegetables farms surrounding the lake; Volpato, pers. obs. 2018). The resilience of nomadic pastoralists in contexts such as North Italy, post-socialist Romania, and the Kenyan Highlands is a testimony to the importance of mobility for livestock husbandry. While witnessing the marginalization of their livelihoods, these pastoralists adapt by seeking access to a variety of scattered plots while establishing an array of relationships with other stakeholders tomaintain the resilience of the pastoral system (Galvin et al. 2008; Easdale et al. 2016).

\section{Conclusions}

We have described the adaptation and resilience of Alpine nomadic pastoralists in response to the loss of grazing grounds following urbanization and intensification of land use in Northwest Italy during the last 50 years by using a variety of landscapes to find grazing resources for their sheep and establishing social networks and relations at multiple levels and with multiple stakeholders (e.g., the EU, local authorities, farmers, migrant communities). Piedmont nomadic shepherds act in the interstices of the mainstream society, navigating marginal contexts: geographically, they use fallow, abandoned, and second-hand plots; economically and socially, they interact with other marginal groups of people; politically, they are at the fringes of society and of legality; culturally, they face hostile attitudes from part of the general public and local authorities and are tolerated at best. Other studies about the resilience of interstitial pastoral systems would prove interesting and give further insights into how nomadic pastoralists adapt and survive in conditions of marginalization, and how mobility is reconfigured into the scattered pieces of land left unused by industrial, agricultural, and conservation land uses. Also, such studies would provide a background and contextual analysis to be used to build and implement strategies at multiple institutional levels that aim to support nomadic herders by improving access to unused and abandoned plots, by including them into the planning and management of regional parks and conservation areas, by recognizing (also economically) their contributions in terms of ecosystem and cultural services, as well as by finding ways to support their products.

\section{Acknowledgements}

We are very thankful to all the shepherds and their families for their patience and kindness during the interviews. We also thank Marzia Verona and Pinulin Ghibaudo for sharing with us their knowledge about Alpine nomadism and shepherds.

\section{Funding}

This research was funded by the Italian Ministry of Education, Universities and Research Funds for this study came from the MIUR through the PRIN project 'Biodiversity and ecosystem services in Sacred Natural Sites (BIOESSaNS)', Nr. 2015P8524C, as well as from the University of Gastronomic Sciences of Pollenzo, Italy.

\section{Authors contribution}

GM conducted fieldwork and analyzed the data, GV drafted the paper, all authors designed the study, composed the literature review, and worked, read and approved the final manuscript.

\section{Literature cited}

AAA. 1998. "Code of ethics of the American Anthropological Association." American $\begin{array}{llll}\text { Anthropological Association } & \text { Accessed } & 15 & \text { March. }\end{array}$ http://www.aaanet.org/profdev/ethics/upload/ethicscode1998.pdf. 
This is the postprint version of the article:

Mattalia, G., Volpato, G., Corvo, P., \& Pieroni, A. (2018). Interstitial but Resilient: Nomadic Shepherds in Piedmont (Northwest

Italy) Amidst Spatial and Social Marginalization. Human ecology, 46(5), 747-757.

Ahmed, A.S. 1982. "Nomadism as ideological expression: The case of Gomal nomads." Economic and Political Weekly 17 (27):1101-1106.

Aime, M., S. Allovio, and P. Viazzo. 2001. Sapersi muovere. Rome: Meltemi.

Akasbi, Z., J. Oldeland, J. Dengler, and M. Finckh. 2012. "Social and ecological constraints on decision making by transhumant pastoralists: a case study from the Moroccan Atlas Mountains." Journal of Mountain Science 9 (3):307-321.

Bernard, H.R. 2006. Research Methods in Anthropology. Qualitative and Quantitative Approaches. 4th ed. ed. Lanham, Maryland: Altamira Press.

Bini, G., and G. Vicquèry. 2013. Fame d'erba: Lassù gli Ultimi.

Blench, R. 2001. 'You can't go home again' Pastoralism in the new millennium. London: Overseas Development Institute.

Borgia, M., ed. 2003. Il ritorno del lupo nelle valli torinesi. Torino: Luna Nuova Editrice.

Bunce, R., M. Pérez-Soba, R. Jongman, A. Gòmez Sal, F. Herzog, and I. Austad, eds. 2004. Transhumance and biodiversity in European mountains, IALE publication series $n r 1$. Wageningen: Alterra Wageningen UR.

Carbonero, C. 2006. "Pecore, parco e territorio." Il Guardiaparco, Bollettino Ufficiale dell'Associazione Italiana Guardie dei Parchi e delle Aree Protette.

Corti, M. 2004. "L'alpeggio nelle Alpi lombarde tra passato e presente." SM Annali di San Michele 17:31-155.

De Marchi, V. 2010. Fame d'erba. Pastori transumanti del Triveneto. https://vimeo.com/25643471.

Dong, S., K.S. Kassam, J.F. Tourrand, and R.B. Boone, eds. 2016. Building resilience of coupled human-natural systems of pastoralism in the developing world: Springer International Publishing.

Eriksson, C. 2011. "What is traditional pastoral farming? The politics of heritage and 'real values' in Swedish summer farms (fäbodbruk)." Pastoralism: Research, Policy and Practice 1 (1).

Errante, J. 2013. "Razze zootecniche a rischio di estinzione: la pecora Frabosana." Vita in Campagna 11.

Falah, G. 1990. "The evolution of semi-nomadism in non-desert environment: The case of Galilee in the 19th century." GeoJournal 21 (4).

Fassio, G., L. Battaglini, V. Porcellana, and P. Viazzo. 2014. "Families in mountain pastoralism today: persistent centrality or "broken traditions"? Ethnographic evidence from the Western Italian Alps." Mountain Research and Development 34:336-343.

Fernandez-Gimenez, M.E., and S. Le Febre. 2006. "Mobility in Pastoral Systems: Dynamic Flux or Downward Trend?" International Journal of Sustainable Development and World Ecology 13:341-362.

Galvin, K.A., R.S. Reid, R.H. Behnke, and N.T. Hobbs, eds. 2008. Fragmentation of Semi-Arid and Arid Landscapes. Consequences for Human and Natural Systems. Dordrecht, The Netherlands: Springer.

Garric, A. 2013. "Des moutons pour tondre en ville, vrai gain pour l'environnement." Le Monde, $12 / 04 / 2013$.

German, L., R. Unks, and E. King. 2017. "Green appropriations through shifting contours of authority and property on a pastoralist commons." The Journal of Peasant Studies 44 (3):631-657.

Huband, S., D.I. McCracken, and A. Mertens. 2010. "Long and short-distance transhumant pastoralism in Romania: past and present drivers of change." Pastoralism: Research, Policy and Practice 1 (1):55-71.

Juler, C. 2014. "După coada oilor: long-distance transhumance and its survival in Romania." Pastoralism: Research, Policy and Practice 4 (1).

Kerven, C., and R.H. Behnke. 2011. "Policies and practices of pastoralism in Europe." Pastoralism: Research, Policy and Practice 1 (1). 
This is the postprint version of the article:

Mattalia, G., Volpato, G., Corvo, P., \& Pieroni, A. (2018). Interstitial but Resilient: Nomadic Shepherds in Piedmont (Northwest

Italy) Amidst Spatial and Social Marginalization. Human ecology, 46(5), 747-757.

Lescureux, N., and J. Linnell. 2010. "Knowledge and perceptions of Macedonian hunters and herders: The influence of species specific ecology of bears, wolves, and lynx." Human Ecology 38 (3):389-399.

Liechti, K., and J. Biber. 2016. "Pastoralism in Europe: characteristics and challenges of highlandlowland transhumance." Revue Scientifique et Technique de l'OIE 35 (2):561-575.

López-i-Gelats, F., E.D.G. Fraser, J.F. Morton, and M.G. Rivera-Ferre. 2016. "What drives the vulnerability of pastoralists to global environmental change? A qualitative meta-analysis." Global Environmental Change 39:258-274.

Lozny, L.R., ed. 2013. Continuity and change in cultural adaptation to mountain environments. New York: Springer.

Mack, G., T. Walter, and C. Flury. 2013. "Seasonal alpine grazing trends in Switzerland: Economic importance and impact on biotic communities." Environmental Science \& Policy 32:48-57.

Manzano, P., and J. Malo. 2006. "Extreme long-distance seed dispersal via sheep." Frontiers in Ecology and the Environment 4 (5):244-248.

Marandola, D., and S. Coderoni. 2015. PSR 2014-2020 - Quadro di sintesi delle principali misure per la conservazione della biodiversità e la sostenibilità ambientale: CTS.

Marucco, F. 2014. Il lupo. Biologia e gestione nelle Alpi ed in Europa: Il Piviere.

Mocarelli, L. 2009. "When the Mountain Serves the City: The Production of Cheese and Wool in Eighteenth-Century Bresciano (Italian Alps)." Nomadic Peoples 13 (2):160-170.

Montanari, M. 2003. "Strutture di produzione e sistemi alimentari nell'alto Medioevo." In Storia dell'alimentazione, edited by J. Fandrin and M. Montanari, 217-222. Rome: Laterza.

Niamir-Fuller, M. 1998. "The resilience of pastoral herding in Sahelian Africa." In Linking Social and Ecological Systems: Management Practices and Social Mechanisms for Building Resilience, edited by F. Berkes, C. Folke and J. Colding, 250-284. Cambridge: Cambridge University Press.

Nori, M. 2014. Pastori a colori. Florence: TRAMed Transumanze Mediterranee, Migration Policy Centre EUI.

Nori, M., and J. Davies. 2007. Change of wind or wind of change? Climate change, adaptation and pastoralism. Nairobi: IUCN.

Nori, M., and V. De Marchi. 2015. "Pastorizia, biodiversità e la sfida dell'immigrazione: il caso del Triveneto." Culture della sostenibilità 15:78-101.

O'Flanagan, P., T. Lasanta Martinez, and M. Errea Abad. 2011. "Restoration of sheep transhumance in the Ebro valley, Aragon, Spain." Geographical Review 101 (4):556-575.

Perco, D. 1982. La pastorizia transumante del Feltrino. Feltre: Centro Documentazione Cultura Popolare.

Pini, R., C. Ravazzi, L. Raiteri, A. Guerreschi, L. Castellano, and R. Comolli. 2017. "From pristine forests to high-altitude pastures: an ecological approach to prehistoric human impact on vegetation and landscapes in the western Italian Alps." Journal of Ecology 105:1580-1597.

Regione Lombardia. 2013. La pastorizia ovina vagante in Lombardia. Milano: Regione Lombardia.

Regione Piemonte. 2008. Caratterizzazione di aree e definizione di indirizzi per la razionalizzazione del pascolo. Turin: IPLA.

Regione Piemonte. 2017. Zootecnia. Turin: IPLA.

Ristorto, M. 1990. Roaschia, cenni storici. Cuneo: Tipografia Ghibaudo.

Robinson, L.W., and F. Berkes. 2010. "Applying Resilience Thinking to Questions of Policy for Pastoralist Systems: Lessons from the Gabra of Northern Kenya." Human Ecology 38:335350.

Rokos, D., and E. Michailidou. 2005. "Policy Options to Support Transhumance and Biodiversity in European Mountains." Mountain Research and Development 25 (1):84-85.

Roletto, G. 1920. "La transumanza in Piemonte." Rivista Geografica Italiana XXVII (IVVIII):114-120. 
This is the postprint version of the article:

Mattalia, G., Volpato, G., Corvo, P., \& Pieroni, A. (2018). Interstitial but Resilient: Nomadic Shepherds in Piedmont (Northwest

Italy) Amidst Spatial and Social Marginalization. Human ecology, 46(5), 747-757.

Ross, L., G. Austrheim, L. Asheim, G. Bjarnason, J. Feilberg, A. Fosaa, A. Hester, Ø. Holand, I. Jónsdóttir, L. Mortensen, A. Mysterud, E. Olsen, A. Skonhoft, J. Speed, G. Steinheim, D. Thompson, and A. Thórhallsdóttir. 2016. "Sheep grazing in the North Atlantic region: A long-term perspective on environmental sustainability." Ambio 45 (5):551-566.

Ruiz, M., and J.P. Ruiz. 1986. "Ecological history of transhumance in Spain." Biological Conservation 37:73-86.

Thornton, PK, J Van de Steeg, A Notenbaert, and M Herrero. 2009. "The impacts of climate change on livestock and livestock systems in developing countries: A review of what we know and what we need to know." Agricultural Systems 101 (3):113-127.

Triboi, R.M. 2017. "Urban pastoralism as environmental tool for sustainable urbanism in Romania and Eastern Europe." Procedia Environmental Sciences 1:1-6.

Verona, M. 2006. Dove vai pastore? Pascolo vagante e transumanza nelle Alpi Occidentali agli albori del XXI secolo. Scarmagno: Priuli e Verlucca.

Verona, M. 2016. Storie di pascolo vagante. Roma: Laterza.

Verona, M., M. Corti, and L. Battaglini. 2010. "L'impatto della predazione lupina sui sistemi pastorali delle valli cuneensi e torinesi." Quaderno SOZOOALP 6:149-167.

Wu, Ning, Muhammad Ismail, Srijana Joshi, Shao-liang Yi, Ritu Meher Shrestha, and Abdul Wahid Jasra. 2014. "Livelihood diversification as an adaptation approach to change in the pastoral Hindu-Kush Himalayan region." Journal of Mountain Science 11 (5):1342-1355. doi: 10.1007/s11629-014-3038-9. 